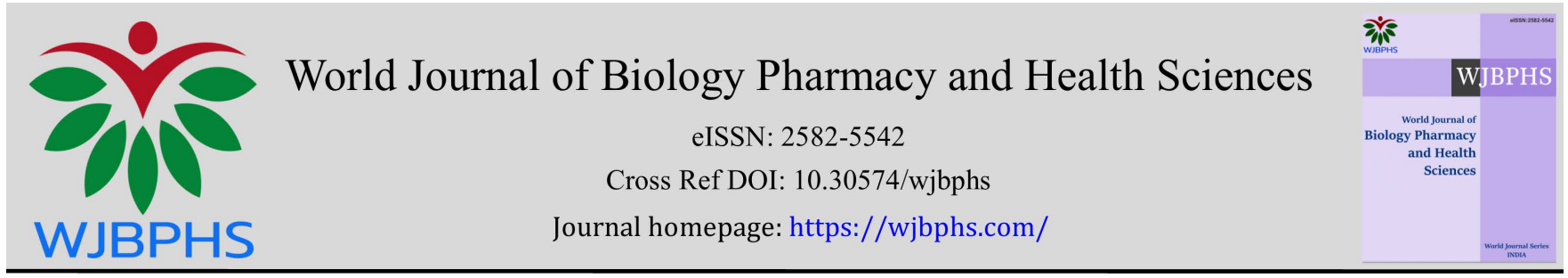

(RESEARCH ARTiCLE)

\title{
Effects of samin yogurt on the liver of adult wistar rats
}

\author{
Uloneme Godwin C 1, ${ }^{*}$ Akukwu Darlington CA ${ }^{1}$ Ezejindu Damian N ${ }^{2}$ Amadi CC ${ }^{1}$ \\ ${ }^{1}$ Department of Anatomy and Neurobiology, Faculty of Basic Medical Sciences, Imo State University, Owerri, Nigeria. \\ 2 Department of Anatomy, Faculty of Basic Medical Sciences, Nnamdi Azikiwe University, Nnewi Campus, Anambra state, \\ Nigeria.
}

World Journal of Biology Pharmacy and Health Sciences, 2021, 06(01), 049-053

Publication history: Received on 13 March 2021; revised on 18 April 2021; accepted on 21 April 2021

Article DOI: https://doi.org/10.30574/wjbphs.2021.6.1.0036

\begin{abstract}
Background: Yogurt is basically fermented milk that is heated and mixed with two types of body friendly bacteria. It is very nutritious and therefore, it is being eaten by all and sundry.

Purpose: The study was designed to determine the effect of yogurt on the liver of adult Wister rats.

Method: A total of twenty four adzult Wister rats bred and harboured at the animal house of Anatomy and Neurobiology department, Imo State University Owerri were used for the study. The rats which weighed between 180 and 220 grammes were separated and housed in four different cages marked A, B, C and D. Each cage contained four rats. The group A served as control group and so received only the normal rat feed and water. Group B rats were administered $2500 \mathrm{mg} / \mathrm{kg}$ body weight of yogurt; group C received $5000 \mathrm{mg} / \mathrm{kg}$ body weight of yogurt why group D was given $10000 \mathrm{mg} / \mathrm{kg}$ body weight of yogurt, all through oral intubation for four weeks. At the end of the four week treatment, the rats were anesthetized in chloroform vapour and the liver was dissected out for histological investigations.

Results: On examining the processed liver tissue, it was observed that there was a mild (for group B), moderate (for group C), and serve (for group D) lymphocyte infiltration on the liver portal tract when compared to the control group which showed very little presence of haepatocytes around a central venule. The effect observed could be described to be dose dependent.
\end{abstract}

Keywords: Haepatocytes; Liver; lymphocytes; Wister rats; Samin Yogurt

\section{Introduction}

Yogurt is a fermented dairy product obtained through anaerobic fermentation of lactose in milks by relevant microorganisms, most of which are classified as pro-biotic (Tull, 1996). The nutritional composition of yogurt include proteins, Vitamins (such as B2 and B12), minerals (such as Calcium, Zinc, Potasium, Magnesium) and fat. The conversion of lactose into lactic acid gives yogurt its characteristic gel-like texture (Braing, 2005; Elson and Hass 2005). In its production, lactose in evaporated whole milks, skimmed milks or fresh cow's milk is converted into lactic acid by a symbiotic bacterial culture of streptococcus thermophilus and lactobacillus bulgaricus growing at temperatures in the range of 40-45oC (Wood, 1985). According to Sanful (2009), many chanaians consume yogurt as a snack or as a probiotic food drink to acid digestion and to re-establish a balance within the intestinal microflora. It is preferred over milk as it contains lactic acid that is readily digested as compared to lactose contained in unfermented milk, and more importantly, being a natural drink with fresh, acidulated taste and addictive flavour, it has prophylactic and therapeutic properties (Roissart and Luquet, 1994). In their work, Flynn and Cashman (1997) reported that about 30-45\% of total phosphorus intake of Western countries is derivable from yogurt. Fermandes et al (1987) advocated use of yogurt in the prevention and treatment of gastrointestinal disorders, management of lactose intolerance and

${ }^{*}$ Corresponding author: Uloneme Godwin C

Department of Anatomy and Neurobiology, Faculty of Basic Medical Sciences, Imo State University, Owerri, Nigeria. 
hypercholesterolaemia and even prevention of neoplastic diseases (Fermandes and Shahani, 1990; Colombel et al, 1987). Since yogurt is now produced and consumed in so many countries of the world (Nigeria inclusive), with its quality depending on the milk used in the manufacturing process, additives present in the product, and manufacturing practices and conditions (Bonczar et al, 2002), a study of its effect on the liver is deemed necessary. This is so because, the liver is a very important organ of the body where very important metabolic activities take place (Moore and Dalley, 2006). Apart from storing glycogen and production of bile, the liver plays a number of vital roles that contribute to the overall well-being of the body. So any form of malfunction or disease of the liver invariably constitutes a major health challenge. (Ryder, 2006). There is a report that has shown that consumption of yogurt leads to improved haepatic enzyme functions, serum total cholesterol, low-density lipoprotein cholesterol levels (Nabavi et al, 2014). This study seeks to determine the effect of samin yogurt on the microanatomy of the liver.

\section{Material and methods}

\subsection{Experimental Animals}

Twenty four female wister rats weighing between 180-220 grammes, and of 8-9 weeks old were used for the study. The animals which were bred in the animal house of the Anatomy and Neurobiology Department of Imo State University Owerri, Nigeria were divide into four groups and placed in separate cages labeled A, B, C and D respectively. The rats which were five in their respective cages were fed ad libitum with rat feed and water. The group A rats that served as the control group received only water and normal rat feed, while the test animals |(Group B, C, and D) were administered varying doses of the yogurt sample twice daily (9am-6pm) for twenty eight days.

\subsection{Procurement of Samin Yogurt}

The yogurt (a product of Samin Foods) was purchased from a popular supermarket in Owerri, Imo State Nigeria.

\subsection{Administration of the Yogurt}

Through oral intubation the rats in group B were administered $2500 \mathrm{mg} / \mathrm{kg}$ body weight of the yogurt sample while group $\mathrm{C}$ rats received $5000 \mathrm{mgkg}$ body weight of the sample. The group D rats were treated with the highest dose of $10,000 \mathrm{mgkg}$ body weight. The entire treatment lasted for twenty eight days.

\subsection{Collection of Samples}

(Liver Tisues). Some twelve hours after the last treatment, the different animal groups were taken to the neuroanatomy laboratory and sacrificed by servical dislocation one after the other. The organ of interest (liver) was then excised and preserved in 10\% normal saline for histological investigations.

\subsection{Histological processing}

This was done in the histology laboratory of the Department of Anatomy where the processed and stained sections were viewed under the microscope and photomicrographs were taken for evaluation.

\section{Results}

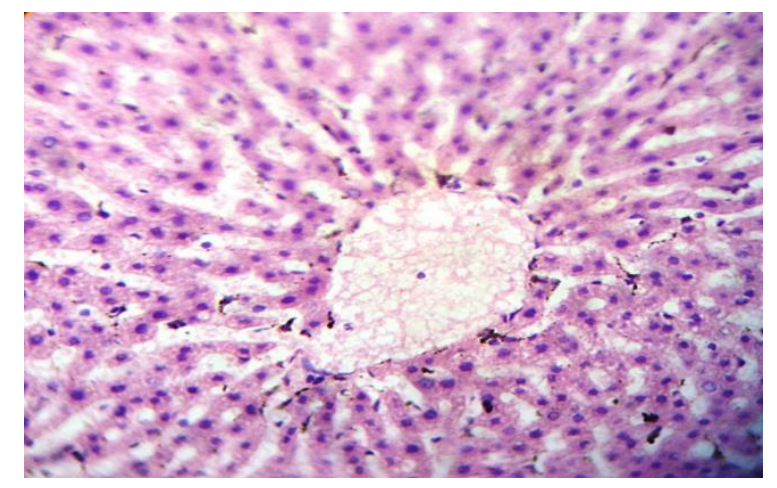

Figure 1 Photomicrograph of the liver from group A (control) showing normal haepatocytes around a central venule $(\times 400 \mathrm{H} \&$ E stain). 


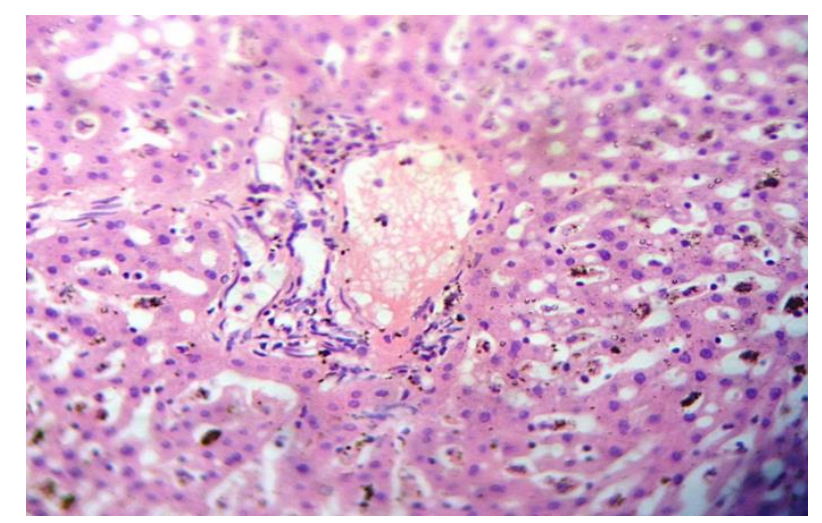

Figure 2 Photomicrograph of liver from group B showing a mild lymphocytic infiltration of the portal tract $(\times 400 \mathrm{H} \&$ E stain)

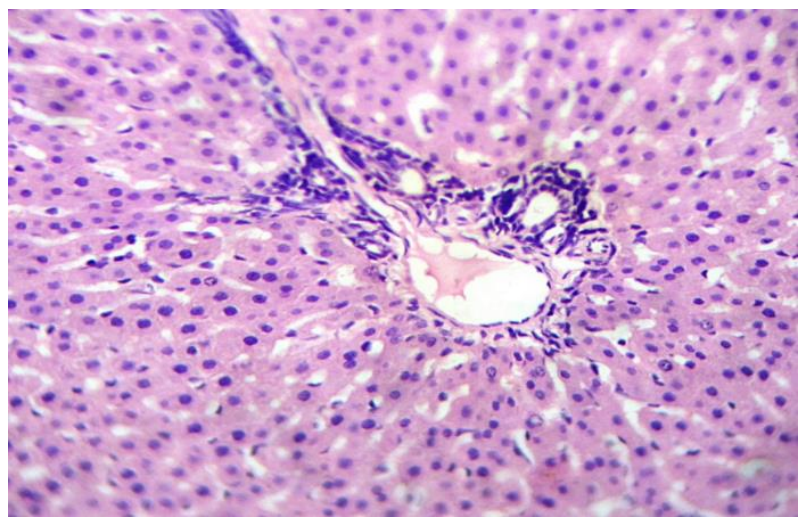

Figure 3 Photomicrograph of liver from group C showing moderate lymphocytic infiltration of the portal tract $(\times 400 \mathrm{H}$ \& E stain)

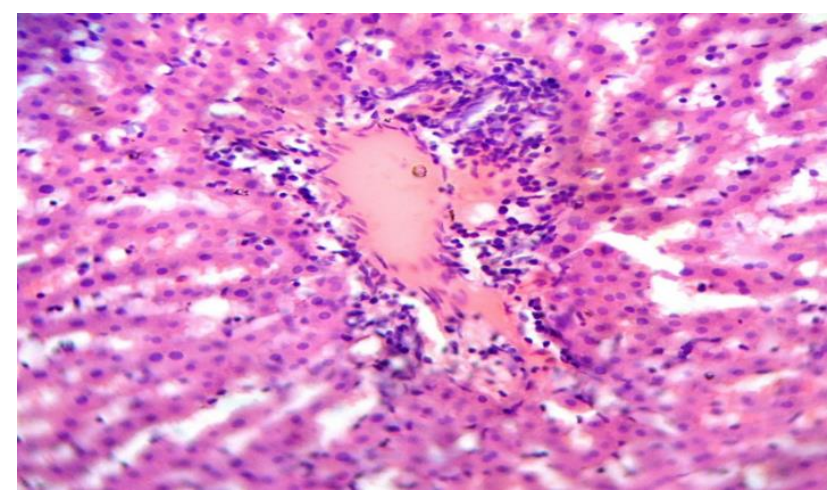

Figure 4 Photomicrograph of liver from group D showing severe lymphocytic infiltration of the portal tract $(\times 400 \mathrm{H} \&$ E stain).

\section{Discussion}

The functional and cellular unit of the liver, the haepatocyte, as seen in the photomicrographs is a large cell with a round shaped nucleus carrying prominent nucleoli. A probe of the group A photomicrograph representative shows the several canaliculi that form hexagonal networks around the liver cells. The interlobular ductules are also seen lined with cuboidal epithelium character-istic of normal liver anatomy. However, photomicrograph representative of group B rats showed some mild lymphocytic infiltration of the liver portal tract. The rats in this group were treated with $2500 \mathrm{mg} / \mathrm{kg}$ body weight of the samin yogurt. By implication, it means that samin yogurt, when administered to wister rats at a concentration as low as $2500 \mathrm{mg} / \mathrm{kg}$ body weight could pose health challenge to the liver. Correspondingly, an investigation of the group $\mathrm{C}$ photomicrograph showed that samin yogurt administered to wister rats at a dose 
concentration of $5000 \mathrm{mg} / \mathrm{kg}$ body weight could actually harm the liver. There was a remarkable and moderate lymphocytic infiltration of the portal tract, an indication that the integrity and functionality of the liver were threatened. On probing the group D photomicrograph representative, it was observed that there was a severe lymphocytic infiltration of the portal tract in addition to the compromised state of the cytoarchitectural integrity of the liver sample investigated. From the aforegoing observations, it could be inferred that consumption of large quantities of the samin yogurt, especially on daily basis could affect the well-being of the liver.

\section{Conclusion}

If samin yogurt consumption is abused, it could distort the normal histologic features and functional integrity of the liver.

\section{Compliance with ethical standards}

\section{Disclosure of conflict of interest}

There is no conflict of interest.

\section{References}

[1] Belewu MA, Belewu KY, Bamidele RA. Cyper-coconut yoghurt: preparation, composition and organoleptie qualities. Partisan Journal of food science and technology. 2010; 1(1): 010-072.

[2] Beniwal RS, Vincent CA, Lenot, Sudhir N, Thomas FI. Rauf AC, Usman AA."A Randomized trial of yogurt for prevention of Antibiotic- associated Diarrhea", Digestive Diseases and science. 2003; 48(10): 2077-2082.

[3] Brainy dictionary. Online www- brainy dictionary. com/milk. 2005; 190-115.

[4] Crane NT, Wilson DB, Cook A, Lewis CJ, Yetley EA, Rader JI. Evaluating food fortification options: general principles revisted with folic acid. Am J Pub. 1995; 85(5): 660-6.

[5] David B. Fankhauser. yogurt making illustrated by professor of Biology and Chemistry U.C. Clermont collage Batavia . 45/03. 2003.

[6] Danaei G, Ding EL, Mozaffarian D, Taylor B, Rehm J, Murray CJ, et al. The Preventable Causes of Death in the United States: Comparative Risk Assessment of Dietary, Lifestyle, and Metabolic Risk Factors. PLoS Med. 2009; 6(4).

[7] Dietz WH, Scanlon KS. Eliminating the use of partially hydrogenated oil in food production and preparation. JAMA. 11 Jul 2012; 308(2): 143-4.

[8] Elson M, Hass MD. 2005. Dairy products online www. health. net /Scr Lartich asp?

[9] Employees of the Office of Foods or the Office of Food Additive Safety of the U.S. Food and Drug Association.

[10] Gladson Nutrition Database.

[11] Ghanson MA. The use of tiger nut (Cyperus esculentus), cow milk, and their composite as substrates for yogurt production. HND Dissertation, Cape coast polytechnic, Cape coats, Ghana. 2008.

[12] Helferich W, Westhoff D. Yogurt: All About It. 1980.

[13] Herh PKW, Cob SM, Roye N, Hedman K. Rheology of Foods: New techniques, capabilities, and Instruments. 2000.

[14] Holden, Joanne. USDA Monitors Levels of Added Sodium in Processed and Prepared Foods, Presentation at the 36th National Nutrient Databank Conference, Empowering Consumers through Advances in Food Composition, March 25-28, 2012, Houston, TX.

[15] Ihekoonye A, Ngoody PO. Integrated food science and technology for the Tropics Macmillan Publishers Ltd. 1985.

[16] Kinsella JE. Functional properties of protein foods; A survey, Critical Review in Food Science and Nutrition. 1976; 228(23): 0-234.

[17] Kirfich IA, Solovieva NV, Leikhter SN, Shidakova NA, Lebedeva OV, Sidorov PI. Probiotics restore bowel flora and improve liver enzymes in human alcohol-induced liver injury: A pilot study. Alcohol. 2008; 42: 675-682.

[18] Kolars JC. yogurt an autodigestiny source of lactose. N. Engl. J med. 1984; 310: 1-3. 
[19] Kosikowski FV. Cheese and fermented milk foods, published by Kosikowski F.V. and Associates, New York. 1982; $1-711$.

[20] Lewis MJ. Physical properties of Food and Food processing systems. Chi Chester Ellis Horwood Ltd. 1987; 108135.

[21] Manna F, Ahmed H, Estefan S, Sharaf H, Eskander E. Sacoharomyces cerevisiac intervention for relieving flutamide - induced hepatotoxicity in male rats. Pharmazie. 2005; 60: 689-695.

[22] McGee, Harold. "Fresh Fermented Milks and Creams." The Science and Lore of the Kitchen. Completely rev. and updated ed. New York: Scriber. 2004.

[23] National Research Council. Dietary Reference Intakes for Thiamin, Riboflavin, Niacin, Vitamin B6, Folate, Vitamin B12, Pantothenic Acid, Biotin, and Choline. Washington, DC: The National Academies Press. 1998.

[24] Osman N, Adawi S, Jeppsson B, Molin G. Endotoxin and D - galactosamine - induced liver injury improved by the administration of lactobacillus, Bifidobacterium \& blueberry Dig liver Dis. 2007; 39: 849-856.

[25] Smiciklas-Wright H, Mitchell DC, Mickle SJ, Cook AJ, Goldman JD. Foods Commonly Eaten in the United States. Quantities. per Eating Occasion and in a Day, 1994-1996. U.S. Department of Agriculture NFS Report No. 2002; 96-5. 